Jurnal Binomial Vol. 3 No. 2 September 2020

\title{
MENINGKATKAN KINERJA GURU IPA DALAM MENETAPKAN NILAI KKM MELALUI TEKNIK COACHING MODEL GROW ME
}

\author{
ARDIANA \\ Dinas Pendidikan, Ardinaarifin1970@gmail.com
}

\begin{abstract}
Abstrak
Tujuan penelitian ini adalah untuk membantu mengembangkan kompetensi guru maka perlu dilakukan suatu model pembinaan yang bersifat sistematis dan menyeluruh sehingga guru dapat meningkatkan kompetensinya, terkhusus dalam menetapkan KKM. Penelitian ini telah dilakukan selama 2 bulan, mulai dari bulan September hingga Oktober 2017. Dalam penelitian tersebut, 19 guru sasaran dalam penelitian ini terlibat aktif dalam kegiatan diskusi dan sharing pengalaman dengan guru IPA yang lain dalam wadah MGMP IPA. Untuk memaksimalkan pemahaman mereka maka penulis memberikan perhatian, bimbingan, dan pendampingan yang lebih banyak dalam menetapkan KKM. Penelitian tindakan sekolah dilaksanakan melalui dua siklus dengan indikator keberhasilan $85 \%$ guru sudah dapat menetapkan KKM. Hasil dari penelitian ini menunjukkan adanya peningkatan yang signifikan. Pada siklus I baru tercapai $65,4 \%$, dan setelah siklus II menunjukkan peningkatan hingga 96,4 \% kemampuan guru menetapkan KKM. Dengan demikian maka diharapkan model pembinaan melalui pendampingan di kegiatan MGMP dapat digunakan untuk membantu dan meningkatkan kemampuan guru dalam mengatasi masalah lainnya.
\end{abstract}

Kata-kata kunci : Kinerja Guru, Kriteria Ketuntasan Minimal (KKM), Model Grow Me.

\section{Abstract}

To help develop teacher competence, it is necessary to carry out a guidance model that is systematic and comprehensive so that teachers can improve their competence, especially in determining KKM. This research has been conducted for 2 months, starting from September to October 2017. In this study, 19 target teachers in this study were actively involved in discussions and sharing experiences with other science teachers in the IPA MGMP forum. To maximize their understanding, the authors provide more attention, guidance, and assistance in determining KKM. The school action research was carried out in two cycles with an indicator of success that $85 \%$ of teachers were able to determine the KKM. The results of this study indicate a significant increase. In the first cycle only reached $65.4 \%$, and after the second cycle showed an increase of up to $96.4 \%$ in the ability of teachers to determine KKM. Thus, it is hoped that the model of guidance through mentoring in MGMP activities can be used to assist and improve the ability of teachers to overcome other problems.

Key words: Teacher Performance, Minimum Completeness Criteria (KKM), Grow Me Model. 


\section{PENDAHULUAN}

Peraturan Menteri Pendidikan dan Kebudayaan Nomor 53 Tahun 2015 tentang Standar Penilaian Hasil Belajar Oleh Pendidik dan satuan pendidikan pada Pendidikan Dasar dan Pendidikan Menengah merupakan acuan utama bagi guru untuk melaksanakan proses penilaian. Kurikulum 2013 merupakan kurikulum berbasis kompetensi. Hal penting yang harus diperhatiakn ketika melaksanakan penilaian dalam kurikulum 2013 adalah KKM, remedial, dan pengayaan.

Kriteria ketuntasan Minimal yang selanjutnya disebut KKM adalah kriteria ketuntasan yang ditentukan oleh satuan pendidikan dengan mengacu pada standar kompetensi lulusan. KKM dirumuskan dengan memperhatikan 3 (tiga) aspek yaitu karakteristik peserta didik (intake), karakterisrik mata pelajaran (kompleksitas materi), dan kondisi satuan pendidikan (daya dukung).

Secara teknis prosedur penentuan KKM mata pelajaran pada satuan pendidikan dapat dilakukan dengan cara berikut: Menghitung jumlah KD setiap mata pelajaran pada masing-masing tingkat kelas dalam satu tahun pelajaran danMenentukan nilai aspek intake, kompleksitas, dan daya dukung setelah menganalisis karakteristik setiap aspek tersebut.

Seharusnya setiap guru mata pelajaran mesti melakukan analisis karaketristik ketiga aspek KKM di atas lalu selanjutnya menetapkan nilai KKM sebagai acuan untuk melaksanakan proses penilaian. Namun kenyataan di lapangan, penulis menemukan masih ada guru yang belum mampu menjelaskan makna dari nilai KKM yang telah ditetapkannya, dan bahkan masih ada beberapa guru yang membiarkan format KKM tersebut kosong.

Ketika penulis melakukan kegiatan supervisi akademik tingkat SMP di 5 kecamatan yang ada di daratan yaitu kecamatan Pangkajene, Minasatene, Balocci, Bungoro, dan Labakkang, penulis menemukan permasalahan yaitu dari 54 orang guru IPA, ada 12 orang yang belum mampu menetapkan KKM dengan benar dan masih ada 7 orang yang betul-betul tidak mampu menetapkan KKM. Padahal setiap awal tahun pelajaran guru seharusnya lebih dahulu menetapkan KKM.

Dari hasil pengamatan dan wawancara lebih lanjut, penulis mendapatkan fakta bahwa 19 guru yang bermasalah tersebut memiliki latar penyebab yang hampir sama yaitu 
mereka belum memahami betul cara menetapkan KKM karena mereka jarang mengikuti kegiatan workshop atau pelatihan atau melakukan pengembangan keprofesionalan. Bahkan ada yang mengakui bahwa faktor jarak, ketidaksesuian jadwal mengaajar dan jadwal kegiatan MGMP, dan kesibukan mengurus anak-anak balita mereka menjadi penyebab ketiadaan kesempatan untuk mengikuti kegiatan MGMP.

Berdasarkan temuan di atas maka penulis berupaya memberi bantuan untuk meningkatkan kinerja guru IPA tersebut dalam menetapkan KKM melalui kegiatan pendampingan menggunakan Teknik Coaching Model GROW ME, yang pelaksanaannya diatur dan dirancang bersama-sama dengan guru yang bermasalah tersebut sehingga dapat mengatasi faktor waktu dan kesibukan.

\section{METODE PENELITIAN}

Desain penelitian ini adalah Penelitian Tindakan Sekolah model Stephen Kemmis, penelitian dilaksanakan dalam 8 minggu yaitu bulan September sampai dengan Oktober 2017. Lokasi Penelitian yang disepakati adalah Sekretariat MGMP IPA di SMPN 1 Bungoro, Kecamatan Bungoro, Kabupaten Pangkajene dan kepulauan.
Penelitian ini direncanakan dalam 2 (dua) siklus, adapun proses kerja penelitian tindakan ini terdiri atas empat langkah yang berlangsung secara siklikal, yaitu: perencanaan, pelaksanaan, pengamatan, dan refleksi. Subjek Penelitian adalah 19 guru mata pelajaran IPA di lima kecamatan daratan Kabupaten Pangkajene dan kepulauan. Guna memperoleh data yang lebih valid digunakan metoda triangulasi yaitu Untuk menilai kinerja guru dalam menetapkan KKM, observasi dilaksanakan oleh 3 orang ( 2 orang pengawas, 1 orang kepala sekolah). Kegiatan ini dimaksudkan untuk mengetahui kemampuan awal guru-guru dalam menetapkan KKM ketika melakukan supervisi akademik. Peneliti/supervisor mengumpulkan KKM yang telah dibuat oleh guru. Kemudian dikaji dan dinilai, diberikan umpan balik berdasarkan 3 (tiga) aspek yang perlu diperhatikan saat menetapkan KKM, yaitu aspek Intake, Kompeksitas, dan daya dukung.

Data-data yang dikumpulkan dalam penelitian ini adalah data primer yaitu data-data yang diproleh secara langsung oleh penulis. Data tersebut diperoleh dari pengamatan atau penilaian dokumen KKM guru, Metode pengumpulan data penelitian ini adalah 
observasi, penilaian dokumen dan wawancara.

Data-data yang terkumpul dianalisis dengan analisis deskriptif dibantu dengan statistik sederhana. Penelitian tindakan sekolah ini dianggap berhasil apabila $85 \%$ guru yang menjadi sasaran penelitian ini sudah mampu menetapkan KKM.

\section{Pelaksanaan Tindakan Siklus I}

Siklus I ini terdiri atas empat tahapan, yaitu Perencanaan, Pelaksanaan, Pengamatan/Pengumpulan Data, dan Refleksi.

Pertama : Perencanaan, kegiatan yang dilaksanakan adalah : merencanakan tahap kegiatan yang akan dilaksanakan sesuai dengan tahapan GROW $M E$, membuat skenario kegiatan GROW $M E$, menyiapkan media, membuat lembar observasi dan membuat instrument penilaian. Kedua : Pelaksanaan, kegiatan yang dilaksanakan adalah : penulis/supervisor dan guru menentukan tujuan yang ingin dicapai, penulis/supervisor dan guru menganalisis kondisi saat sekarang dalam hal kemampuan dalam menetapkan KKM yang masih rendah dan upaya yang pernah dilakukan, penulis/supervisor dan guru mengeksplorasi berbagai alternatif solusi untuk mencapai tujuan, penulis/supervisor dan guru menetapkan rencana tindakan pemecahan masalah, lalu mengidentifikasi langkahlangkahnya, hambatan, dukungan, serta waktu yang diperlukan, melaksanakan tindakan pemecahan masalah yang telah ditetapkan bersama, dengan mengikuti langkah-langkah tindakan yang telah disepakati bersama dan mendokumentasikan tindakan pemecahan bersama untuk menamukan hambatan, dukungan, serta konsistensi waktu yang dibutuhkan.

Ketiga : Observasi, kegiatan yang dilaksanakan adalah : Penulis/supervisor melakukan pengamatan untuk mengumpulkan data dengan menggunakan lembar observasi, mereview proses pencapaian tujuan, posisi, waktu dan dukungan yang dibutuhkan untuk mencapai tujuan tahapan GROW, Penulis/supervisor dan guru berbagi pengalaman tentang hasil pengamatan dan Penulis/supervisor memberi umpan balik yang konstruktif dan motivatif. Keempat : Refleksi, kegiatan yang dilaksanakan adalah : mengevaluasi tindakan yang telah dilakukan, dan memutuskan apakah masalah itu tuntas atau masih perlu dilanjutkan tindakan lain dalam siklus berikutnya dan hasil yang diperoleh dari 
Jurnal Binomial Vol. 3 No. 2 September 2020

tugas akhir guru, tingkat keaktifan dan tingkat komitmen akan dianalisis. Apabila masih ada peserta yang belum mencapai indikator keberhasilan maka akan dicari kelemahan-kelemahannya untuk diperbaiki pada siklus kedua.

\section{Pelaksanaan Siklus II}

Siklus kedua ini, akan dilaksanakan seandainya hasil-hasil pada siklus I belum mencapai indikator kinerja. Kegiatan direncanakan terdiri dari beberapa tahapan yaitu :

Pertama : Perencanaan, kegiatan yang dilaksanakan adalah : merencanakan tahap kegiatan yang akan dilaksanakan sesuai dengan tahapan GROW ME, membuat skenario perbaikan dari kegiatan GROW ME, menyiapkan media , membuat lembar observasi danmembuat instrument penilaian. Kedua : Pelaksanaan, kegiatan yang dilaksanakan adalah : penulis/supervisor dan guru menentukan tujuan yang ingin dicapai, penulis/supervisor dan guru menganalisis kondisi saat sekarang dalam hal kemampuan dalam menetapkan KKM yang masih rendah dan upaya yang pernah dilakukan, penulis/supervisor dan guru mengeksplorasi berbagai alternatif solusi untuk mencapai tujuan, penulis/supervisor dan guru menetapkan rencana tindakan pemecahan masalah, lalu mengidentifikasi langkahlangkahnya, hambatan, dukungan, serta waktu yang diperlukan, melaksanakan tindakan pemecahan masalah yang telah ditetapkan bersama, dengan mengikuti langkah-langkah tindakan yang telah disepakati bersama dan mendokumentasikan tindakan pemecahan bersama untuk menamukan hambatan, dukungan, serta konsistensi waktu yang dibutuhkan. Ketiga : Observasi, kegiatan yang dilaksanakan adalah : Penulis/supervisor melakukan pengamatan untuk mengumpulkan data dengan menggunakan lembar observasi, mereview proses pencapaian tujuan, posisi, waktu dan dukungan yang dibutuhkan untuk mencapai tujuan tahapan GROW, Penulis/supervisor dan guru berbagi pengalaman tentang hasil pengamatan dan penulis/supervisor memberi umpan balik yang konstruktif dan motivatif. Keempat : Refleksi, kegiatan yang dilaksanakan adalah :mengevaluasi tindakan yang telah dilakukan, dan memutuskan apakah masalah itu tuntas atau masih perlu dilanjutkan tindakan lain dalam siklus berikutnya, dan hasil yang diperoleh dari tugas akhir guru, tingkat keaktifan dan tingkat komitmen akan dianalisis. Apabila masih ada peserta yang belum 
Jurnal Binomial Vol. 3 No. 2 September 2020

mencapai indikator keberhasilan maka akan dicari kelemahan-kelemahannya untuk diperbaiki pada siklus ketiga.

\section{HASIL DAN PEMBAHASAN}

Hasil pelaksanaan Tindakan Siklus I dan Refleksi

Pelaksanaan siklus I, sesuai dengan kesepakatan coach dan coachee maka telah dipilih dan ditetapkan satu tindakan pemecahan masalah yaitu metode diskusi kelompok. Pada tindakan ini coach (penulis/peneliti) membantu coachee (peserta/guru-guru) dengan cara memfasilitasi terjadinya diskusi kelompok untuk menyelesaikan permasalahan yang mereka hadapi dalam menetapkan KKM. Coach memberikan materi dengan menggunakan media powerpoint, printout contoh KKM yang baik, dan memfasilitasi diskusi lanjutan melalui whatsApp jika ada hal yang masih perlu didiskusikan.

Hasil pelaksanaan tindakan pada siklus I dapat disimpulkan bahwa masih ada aspek-aspek yang belum memenuhi kriteria yang diinginkan.
Tabel 1. Rekapitulasi aspek-aspek yang sudah dan belum mencapai standar

\begin{tabular}{|c|c|c|c|}
\hline \multirow[t]{2}{*}{ No } & \multirow[t]{2}{*}{ Aspek } & \multicolumn{2}{|c|}{$\begin{array}{c}\text { Ketercapaian } \\
\text { Standar }\end{array}$} \\
\hline & & Sudah & Belum \\
\hline 1 & $\begin{array}{l}\text { Kemampuan } \\
\text { merumuskan } \\
\text { indikator }\end{array}$ & $61,50 \%$ & $38,50 \%$ \\
\hline 2 & $\begin{array}{l}\text { Kemampuan } \\
\text { menetapkan } \\
\text { nilai } \\
\text { kompleksitas }\end{array}$ & $23,10 \%$ & $76,90 \%$ \\
\hline 3 & $\begin{array}{l}\text { Kemampuan } \\
\text { menetapkan } \\
\text { nilai daya } \\
\text { dukung }\end{array}$ & $69,20 \%$ & $30,80 \%$ \\
\hline 4 & $\begin{array}{l}\text { Kemampuan } \\
\text { menetapkan } \\
\text { nilai intake }\end{array}$ & $46,10 \%$ & $53,90 \%$ \\
\hline 5 & $\begin{array}{l}\text { Kemampuan } \\
\text { menetapkan } \\
\text { KKM } \\
\text { Indikator }\end{array}$ & $38,50 \%$ & $61,50 \%$ \\
\hline 6 & $\begin{array}{l}\text { Kemampuan } \\
\text { menetapkan } \\
\text { KKM KD }\end{array}$ & $84,60 \%$ & $15,40 \%$ \\
\hline 7 & $\begin{array}{l}\text { Kemampuan } \\
\text { menetapkan } \\
\text { KKM SK } \\
\end{array}$ & $100 \%$ & - \\
\hline 8 & $\begin{array}{l}\text { Kemampuan } \\
\text { menetapkan } \\
\text { KKM MP } \\
\end{array}$ & $100 \%$ & - \\
\hline & Jumlah & 523 & 277 \\
\hline & Rata-rata & $65,40 \%$ & $34,60 \%$ \\
\hline
\end{tabular}

Hasil pengamatan penulis dalam hal keaktifan peserta selama proses pelaksanaan tindakan siklus I 
Tabel 2. Tingkat keaktifan peserta

\begin{tabular}{|c|l|c|c|}
\hline No & \multicolumn{1}{|c|}{ Kriteria } & Skor & $\%$ \\
\hline 1 & Kurang Aktif & 6 & $31,58 \%$ \\
\hline 2 & Cukup Aktif & 8 & $42,10 \%$ \\
\hline 3 & Aktif & 5 & $26,31 \%$ \\
\hline 4 & Sangat aktif & - & \\
\hline & Jumlah & 19 & $100 \%$ \\
\hline
\end{tabular}

\section{Refleksi}

Dari penelitian tindakan siklus I, dengan menggunakan lembar observasi dan instrument yang telah disepakati, diperoleh hasil sebagai berikut : Kemampuan coachee (peserta/guru) dalam menetapkan KKM yang memenuhi standar yakni hanya 65,40\% (tabel 1), belum mencapai harapan $80 \%$ yang diharapkan, Tingkat keaktifan coachee (peserta/guru) masih kurang, hal ini ditunjukkan pada tabel 2.

Mencermati hasil tindakan siklus I di atas, ternyata hasilnya belum sesuai dengan indikator keberhasilan yang diharapkan yaitu $85 \%$, baik kemampuan guru dalam menetapkan KKM maupun keaktifannya. Dari hasil observasi dan analisa di lapangan, maka diperoleh catatan tindakan yang perlu diperbaiki: Metode diskusi kelompok yang dipilih, perlu dipertajam dengan tindakan kerja kelompok, dimana coachee (peserta/guru) langsung berlatih dan bekerja sama dalam membuat dan menetapkan KKM, Metode kerja kelompok yang dipilih, perlu dibekali dengan kertas kerja (work sheet) sehingga seluruh peserta akan terlibat aktif dalam menyelesaikannya. Dan Menyiapkan waktu untuk presentasi agar terbuka ruang diskusi yang lebih terbuka untuk membantu guru menyelesaikan masalahnya dalam menetapkan KKM.

Hasil pelaksanaan Tindakan Siklus II dan Refleksi

Pelaksanaan siklus II, sesuai dengan kesepakatan coach dan coachee maka telah dipilih dan ditetapkan tindakan pemecahan masalah yaitu metode kerja kelompok. Pada tindakan ini coach (penulis/peneliti) membantu coachee (peserta/guru-guru) dengan cara memfasilitasi terjadinya diskusi kelompok yang dipertajam dengan kegiatan kerja kelompok untuk menyelesaikan permasalahan yang mereka hadapi dalam menetapkan KKM. Coach menyiapkan kertas kerja, memberikan materi dengan menggunakan media powerpoint, printout contoh KKM yang baik, dan memfasilitasi diskusi lanjutan melalui whatsApp jika ada hal yang masih perlu didiskusikan.

Hasil pelaksanaan tindakan pada siklus II dapat disimpulkan bahwa masih 
ada aspek-aspek yang belum memenuhi kriteria yang diinginkan.

Tabel 3. Rekapitulasi aspek-aspek yang sudah dan belum mencapai standar

\begin{tabular}{|c|c|c|c|}
\hline \multirow[t]{2}{*}{ No } & \multirow[t]{2}{*}{ Aspek } & \multicolumn{2}{|c|}{$\begin{array}{c}\text { Ketercapaian } \\
\text { Standar }\end{array}$} \\
\hline & & Sudah & Belum \\
\hline 1 & $\begin{array}{l}\text { Kemampuan } \\
\text { merumuskan } \\
\text { indikator }\end{array}$ & $100 \%$ & $0 \%$ \\
\hline 2 & $\begin{array}{l}\text { Kemampuan } \\
\text { menetapkan } \\
\text { nilai } \\
\text { kompleksitas }\end{array}$ & $\begin{array}{c}84,60 \\
\% \\
\end{array}$ & $\begin{array}{c}15,40 \\
\% \\
\end{array}$ \\
\hline 3 & $\begin{array}{l}\text { Kemampuan } \\
\text { menetapkan } \\
\text { nilai daya } \\
\text { dukung }\end{array}$ & $\begin{array}{c}92,30 \\
\%\end{array}$ & $7,70 \%$ \\
\hline 4 & $\begin{array}{l}\text { Kemampuan } \\
\text { menetapkan } \\
\text { nilai intake }\end{array}$ & $100 \%$ & $0 \%$ \\
\hline 5 & $\begin{array}{l}\text { Kemampuan } \\
\text { menetapkan } \\
\text { KKM Indikator }\end{array}$ & $\begin{array}{c}92,30 \\
\%\end{array}$ & $7,70 \%$ \\
\hline 6 & $\begin{array}{l}\text { Kemampuan } \\
\text { menetapkan } \\
\text { KKM KD }\end{array}$ & $100 \%$ & $0 \%$ \\
\hline 7 & $\begin{array}{l}\text { Kemampuan } \\
\text { menetapkan } \\
\text { KKM SK }\end{array}$ & $100 \%$ & $0 \%$ \\
\hline 8 & $\begin{array}{l}\text { Kemampuan } \\
\text { menetapkan } \\
\text { KKM MP } \\
\end{array}$ & $100 \%$ & $0 \%$ \\
\hline & Jumlah & 769,20 & 30,80 \\
\hline & Rata-rata & $\begin{array}{c}96,20 \\
\%\end{array}$ & $3,80 \%$ \\
\hline
\end{tabular}

Hasil pengamatan penulis dalam hal keaktifan peserta selama proses pelaksanaan tindakan siklus II.
Tabel 4. Tingkat keaktifan peserta

\begin{tabular}{|c|l|c|c|}
\hline $\begin{array}{c}\text { N } \\
\text { o }\end{array}$ & \multicolumn{1}{|c|}{ Kriteria } & Skor & $\%$ \\
\hline 1 & Kurang Aktif & - & - \\
\hline 2 & Cukup Aktif & 4 & $21,05 \%$ \\
\hline 3 & Aktif & 5 & $26,32 \%$ \\
\hline 4 & Sangat aktif & 10 & $52,63 \%$ \\
\hline \multicolumn{2}{r|}{ Jumlah } & 19 & $100 \%$ \\
\hline
\end{tabular}

Refleksi

Dari penelitian tindakan siklus II, dengan menggunakan lembar observasi dan instrument yang telah disepakati, diperoleh hasil sebagai berikut: Kemampuan coachee (peserta/guru) dalam menetapkan KKM yang memenuhi standar yakni hanya $96,20 \%$ (tabel 3), sudah mencapai harapan $80 \%$ yang diharapkan, Tingkat keaktifan coachee (peserta/guru) menunjukkan peningkatan yang signifikan, hal ini ditunjukkan pada tabel 4.

Mencermati hasil tindakan siklus II di atas, ternyata hasilnya sudah sesuai dengan indikator keberhasilan yang diharapkan yaitu 85\%, bahkan melebihi yaitu $96,20 \%$.

Dari hasil observasi dan analisa di lapangan, maka diperoleh catatan tindakan yang perlu diperbaiki: Metode diskusi kelompok yang dipilih, yang disertai kerja kelompok jauh lebih efektif dan efisien dalam membantu 
guru/peserta. Metode kerja kelompok yang dilengkapi dengan kertas kerja (work sheet) membantu guru untuk langsung mengaplikasikan informasi yang diterimanya sehingga lebih mudah memahami cara menetapkan KKM. Dan diperlukan waktu yang cukup banyak untuk bekerja dan presentasi agar terbuka ruang diskusi yang lebih terbuka un tuk membantu guru menyelesaikan masalahnya dalam menetapkan KKM.

Perbandingan peningkatan kinerja hasil Pelaksanaan Cooaching model GROW ME antara Siklus I dan Siklus II

Perbandingan peningkatan kinerja hasil pelaksanaan Cooaching model GROW ME antara siklus I dan siklus II terlihat pada table di bawah ini:

Tabel 5. Perbandingan hasil yang dicapai Antara Siklus I dan Siklus II

\begin{tabular}{|c|l|l|l|}
\hline \multirow{2}{*}{$\begin{array}{c}\text { No } \\
\cdot\end{array}$} & \multicolumn{1}{|c|}{ Aspek } & \multicolumn{2}{|c|}{$\begin{array}{c}\text { Hasil yang } \\
\text { dicapai }\end{array}$} \\
\cline { 3 - 4 } & $\begin{array}{l}\text { Siklus } \\
\text { I }\end{array}$ & $\begin{array}{l}\text { Siklus } \\
\text { II }\end{array}$ \\
\hline 1 & $\begin{array}{l}\text { Kemampuan } \\
\text { merumuskan } \\
\text { indikator }\end{array}$ & $\begin{array}{l}61,50 \\
\%\end{array}$ & $100 \%$ \\
\hline \multirow{2}{*}{2} & $\begin{array}{l}\text { Kemampuan } \\
\text { menetapkan } \\
\text { nilai }\end{array}$ & $\begin{array}{l}23,10 \\
\text { kompleksitas }\end{array}$ & $\begin{array}{l}84,60 \\
\%\end{array}$ \\
\hline 3 & $\begin{array}{l}\text { Kemampuan } \\
\text { menetapkan } \\
\text { nilai daya }\end{array}$ & $\begin{array}{l}69,20 \\
\%\end{array}$ & $\begin{array}{l}92,30 \\
\%\end{array}$ \\
\hline
\end{tabular}

\begin{tabular}{|c|c|c|c|}
\hline & dukung & & \\
\hline 4 & $\begin{array}{l}\text { Kemampuan } \\
\text { menetapkan } \\
\text { nilai intake }\end{array}$ & $\begin{array}{l}46,10 \\
\%\end{array}$ & $100 \%$ \\
\hline 5 & $\begin{array}{l}\text { Kemampuan } \\
\text { menetapkan } \\
\text { KKM Indikator }\end{array}$ & $\begin{array}{l}38,50 \\
\%\end{array}$ & $\begin{array}{l}92,30 \\
\%\end{array}$ \\
\hline 6 & $\begin{array}{l}\text { Kemampuan } \\
\text { menetapkan } \\
\text { KKM KD }\end{array}$ & $\begin{array}{l}84,60 \\
\%\end{array}$ & $100 \%$ \\
\hline 7 & $\begin{array}{l}\text { Kemampuan } \\
\text { menetapkan } \\
\text { KKM SK }\end{array}$ & $100 \%$ & $100 \%$ \\
\hline 8 & $\begin{array}{l}\text { Kemampuan } \\
\text { menetapkan } \\
\text { KKM MP } \\
\end{array}$ & $100 \%$ & $100 \%$ \\
\hline & Jumlah & 523 & 769,2 \\
\hline & Rata-rata & $65,4 \%$ & $96,2 \%$ \\
\hline
\end{tabular}

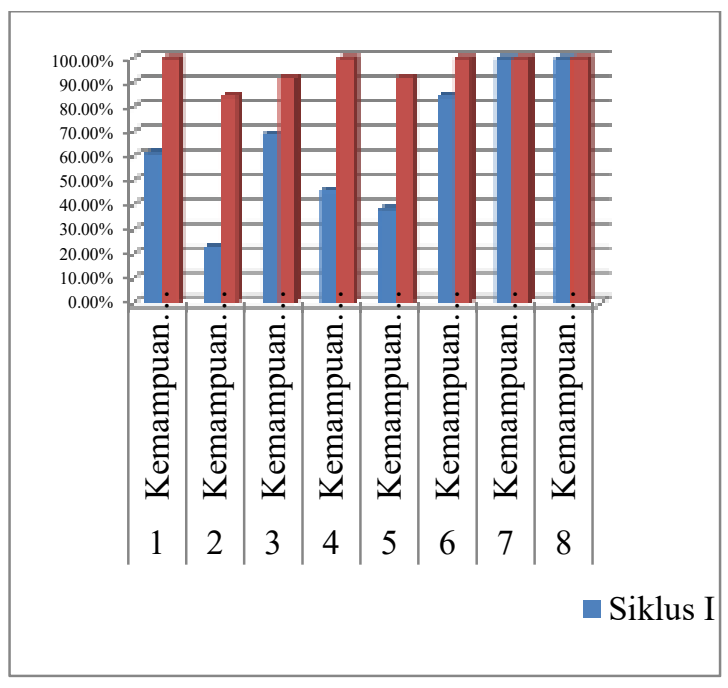

Gambar 1. statistik Perbandingan hasil kinerja yang dicapai antara Siklus I dan Siklus II

Adapun rata-rata setiap aspek adalah pada siklus I $65,40 \%$ dan pada siklus II 96,30\%. Nilai tersebut menunjukkan peningkatan kinerja guru dalam menetapkan KKM yang signifikan dan telah melebihi indikator keberhasilan yang ditetapkan yaitu $85 \%$. Dengan hasil 
tersebut maka penelitian ini hanya sampai pada siklus II sesuai dengan rencana sebelumnya.

Perbandingan tingkat keaktifan guru atau peserta pada siklus I dan siklus II dapat dilihat pada table dibawah ini:

Tabel 7. Perbandingan keaktifan guru pada siklus I dan siklus II

\begin{tabular}{|c|c|c|c|}
\hline \multirow{2}{*}{ No. } & \multirow{2}{*}{ Kriteria } & \multicolumn{2}{|c|}{$\begin{array}{c}\text { Tingkat Keaktifan } \\
\text { Peserta }\end{array}$} \\
\hline & & Siklus I & $\begin{array}{l}\text { Siklus } \\
\text { II }\end{array}$ \\
\hline 1 & \begin{tabular}{|l} 
Kurang \\
Aktif
\end{tabular} & $31,58 \%$ & $0 \%$ \\
\hline 2 & \begin{tabular}{|l|} 
Cukup \\
Aktif \\
\end{tabular} & $42,10 \%$ & $21,05 \%$ \\
\hline 3 & Aktif & $26,31 \%$ & $26,32 \%$ \\
\hline 4 & $\begin{array}{l}\text { Sangat } \\
\text { Aktif } \\
\end{array}$ & $0 \%$ & $52,63 \%$ \\
\hline \multicolumn{2}{|r|}{ Jumlah } & $100 \%$ & $100 \%$ \\
\hline
\end{tabular}

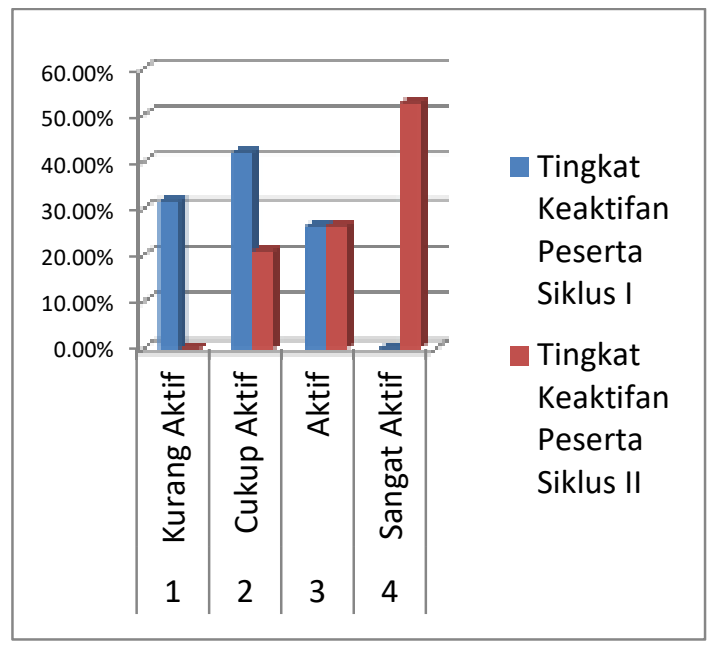

Gambar 2. Perbandingan hasil keaktifan yang dicapai antara Siklus I dan Siklus II

Adapun rata-rata tingkat keaktifan guru/peserta adalah pada siklus I dan siklus II menunjukkan perbedaan dan peningkatan yang menggembirakan. Pada Siklus I, peserta yang kurang aktif adalah $31,58 \%$, yang cukup aktif $42,10 \%$, yang aktif $26,31 \%$, dan yang sangat aktif $0 \%$. Sedangkan pada siklus II, peserta yang kurang aktif $0 \%$, yang cukup aktif $21,05 \%$, yang aktif $26,32 \%$, dan yang sangat aktif 52,63\%. Dengan demikian terjadi peningkatan keaktifan yang signifikan.

\section{KESIMPULAN}

Dari hasil-hasil yang dipaparkan pada Bab IV, dapat dibuat simpulan bahwa teknik cooching model GROW $M E$ dapat meningkatkan kinerja guru IPA dalam menetapkan KKM. Hal tersebut nampak pada peningkatan kinerja yang signifikan dari hasil penelitian, yaitu di siklus I diperoleh hasil rata-rata $65,40 \%$ dan siklus II diperoleh hasil rata-rata $96,30 \%$.

Indikator keberhasilan

peningkatan kinerja guru dalam menetapkan KKM yang diharapkan yaitu $85 \%$ telah tercapai dalam penelitian ini, bahkan melebihi indikator tersebut karena berhasil memperoleh hasil 96,20\%.

Pemilihan metode diskusi kelompok sangat baik dipadukan dengan metode kerja kelompok karena mampu meningkatkan keaktifan guru/peserta 
dalam kegiatan pelatihan secara signifikan.

\section{UCAPAN TERIMA KASIH}

Ucapan Terima kasih disampaikan kepada semua pihak yang telah membantu penulis dalam menyelesaikan penelitian ini baik dalam bentuk doa maupun dukungan yang diberikan.

\section{DAFTAR PUSTAKA}

Anonim, 2008. Petunjuk Teknis Penelitian Tindakan Sekolah (School Action Research) Peningkatan Kompetensi Supervisi Pengawas Sekolah SMA/SMK. Jakarta: Departemen Pendidikan nasional Dirjen PMPTS

Ari Ginanjar Agustian, 2004. Rahasia Sukses Membnagkitkan ESQ Power, Jakarta: Arga, cetakan ke6

Badan Nasional Standar pendidikan, 2006. Naskah Akademik Tentang Standar Pengawas Satuan Pendidikan. Jakarta: Direktorat Pendidikan

Badan Pengembangan Sumber Daya Manusia Pendidikan dan Kebudayaan Dan Penjaminan Mutu Pendidikan, 2014. Prosedur Operasional Standar; penyelenggaraan Pelatihan Implementasi Kurikulum 2013 Untuk Pengawas sekolah. Jakarta: Pusat Pengembangan Tenaga Kependidikan
Berger, P. and T. Luckman. 1967. The Social Construction of Reality. London. Allen Lane

Direktorat Pembinaan Sekolah Menengah Pertama, 2017. Panduan Penilaian Oleh Pendidik dan Satuan Pendidikan Untuk Sekolah Menengah pertama. Jakarta: Departemen Pendidikan dan kebudayaan Dirjen Pendidikan Dasar dan Menengah

Dr. Muhammad Usman najati, 2005. Psikologi Nabi, (terjemahan. Hedi Fajar). Bandung: Pustaka Nur Hidayah/IKAPI

Drs. Ngalim Purwanto, 1990. Psikologi Pendidikan. Bandung: PT Remaja Rosdakarya

Muhammad Rabbi Muhammad jauhari, 2006. Akhlaquna (terjemahan. Dadang Sobar Ali). Bandung: Pustaka Setia

Mulyasa, E, 2008. Kurikulum Satuan Tingkat Pendidikan. Bandung: Remaja Rosdakarya

Prof. Dr. H. Jalaluddin, 2004. Psikologi Agama; Memahami Perilaku keagamaan dengan mengaplikasikan Prinsip-Prinsip Psikologi, edisi Revisi. Jakarta: PT Raja Grafindo

Sardiman, 2009. Interaksi dan Motivasi belajar Mengajar. Jakarta: Raja Grafindo perkasa

Undang-Undang Nomor 14 tahun 2005 tentang Guru dan Dosen 
Depdikbud. 1992. Buku Pedoman Penyelenggaraan Musyawarah Guru Mata Pelajaran. Jakarta : Depdikbud.

Depdiknas. 2005. Peraturan Pemerintah Nomor 19 tahun 2005 tentang Standar Nasional Pendidikan. Jakarta : Depdiknas.

Depdiknas. 2007. Peraturan Menteri Pendidikan Nasional No. 16 tahun 2007 tentang Kualifikasi Akademik dan Kompetensi Guru. Jakarta : Depdiknas.

Depdiknas. 2007. Peraturan Menteri Pendidikan dan Kebudayaan No.53 tahun 2015 Tentang Standar Proses Pendidikan Dasar dan Menengah. Jakarta : Depdiknas. 